\title{
TEKNOLOGI UNTUK UKM SERVER PULSA ALL OPERATOR
}

\author{
Dinny Wahyu Widarti ${ }^{1)}$, Dian Wahyuningsih ${ }^{2)}$, Linda Suvi Rahmawati ${ }^{3)}$, Fitri Marisa $^{4)}$ \\ 1,2,3) STIMATA Malang \\ 4) Universitas Widyagama Malang \\ e-mail : ${ }^{1)}$ dinnywidarti@gmail.com
}

\begin{abstract}
Abstrak
Server pulsa all operator adalah distributor pulsa elektrik semua operator seluler dan PLN Prabayar dimana proses penjualannya melalui sistem online menggunakan perangkat komputer, handphone Siemen C55 sebagai alat modulasi dan modem untuk akses internet yang dikendalikan oleh perangkat lunak dengan metode sms gateway dan akses hangout. Server pulsa sangat bergantung pada keberadaan listrik dan akses internet. Keberadaan server pulsa all operator sangat pesat perkembangannya dalam sepuluh tahun terakhir ini, khususnya di kabupaten Malang. Kabupaten Malang dikenal sebagai salah satu pemasok terbesar pulsa all operator di Indonesia. Dari perkembangannya, server pulsa all operator sangat yang terprospek untuk lebih dikembangkan mengingat semakin meningkatnya kebutuhan pulsa elektrik. Namun ada beberapa permasalahan yang dihadapi UKM Pulsa All Operator) antara lain: 1) tidak ada alat alternatif yang dapat membackup daya listrik secara otomatis tanpa memadamkan komputer jika sewaktu- waktu ada pemadaman listrik, 2) semakin terbatasnya keberadaan handphone Siemen C55 di pasaran karena sudah tidak diproduksi lagi, dan sebagai alternatif telah tersedia perangkat rangkaian modulasi yang berfungsi sama seperti handphone Siemen C55 namun harganya yang relatif mahal sehingga sulit terjangkau oleh daya beli UKM, 3) manajemen keuangan belum baik mengingat perputaran transaksi yang relatif cepat, dan 4) Belum adanya legalitas hukum dari UKM mitra. Maka tindakan yang akan dilakukan adalah 1) membuat rangkaian alat penyedia daya listrik secara otomatis sehingga proses transaksi dapat lebih lancar meskipun pada saat listrik padam, 2) mengupayakan rangkaian alat modulasi yang lebih representatif (modem pool) sebagai pengganti handphone siemens C55 sehingga kebutuhan alat modulasi terpenuhi dan lebih efektif, 3) membuat aplikasi keuangan server pulsa, dan 4) pendampingan kepengurusan CV. Hasil yang telah dicapai adalah : rangkaian alat penyedia daya listrik yang dapat membantu proses kelangsungan proses transaksi, terwujudnya alat rangkaian modulasi (modem pool) yang dapat memenuhi kebutuhan dan sekaligus mempercepat proses transaksi, aplikasi pengelolaan keuangan, dan terdaftarnya UKM sebagai badan hukum CV, dan HKI.
\end{abstract}

Kata Kunci : Model pool, Alat inverter, Badan Hukum, Server Pulsa Reload.

\section{PENDAHULUAN}

Server pulsa all operator saat ini menjadi peluang bisnis yang cukup menjanjikan karena kebutuhan masyarakat akan pulsa telah menjadi salah satu kebutuhan pokok. Pada sepuluh tahun terakhir ini keberadaan server pulsa all operator sangat pesat perkembangannya, khususnya di kabupaten Malang. Kabupaten Malang dikenal sebagai salah satu daerah dengan jumlah pengusaha server terbanyak di Indonesia, selain jakarta. Oleh karena itu persaingan usaha bidang ini di wilayah kabupaten Malang sangat ketat. Untuk itu pemilik usaha server pulsa harus meningkatkan pelayanan dan kelancaran transaksi agar bisa lebih bersaing, karena tidak kurang server pulsa tidak bisa bertahan yang biasanya dikarenakan fasilitas layanan yang kurang baik dan pengelolaan manajemen yang kurang efektif, meskipun dilihat perkembangannya server pulsa all operator sangat yang terprospek untuk lebih dikembangkan mengingat semakin meningkatnya kebutuhan pulsa elektrik.

Sebagai obyek penelitian kegiatan ini adalah melibatkan dua UKM Server Pulsa yang berada di desa yang berbeda yaitu desa Senggreng Tegalgondo. Meskipun kedua mitra ini berjarak cukup jauh namun dengan koneksi internet tidak menghalangi keduanya untuk melakukan kerjasama seperti sharing stok pulsa maupun sharing informasi. Keberadaan usaha mitra selama ini dirasakan cukup memiliki peran di desanya masing-masing. 
Keberadaan mitra memberi kemudahan para penjual akhir seperti konter handphone, maupun toko untuk mengambil stok di tempat mitra yang jaraknya relatif dekat. Dengan adanya mitra juga menjadi pendorong bagi perseorangan seperti ibu rumah tangga menjadi member dan berjualan pulsa sehingga dapat menambah pendapatan keluarga.

Dengan beberapa permasalahan yang ada maka dirumuskan beberapa upaya bidang teknologi untuk menyelesaikan permasalahan mitra antara lain: 1) membuat rangkaian alat penyedia daya listrik secara otomatis sehingga proses transaksi dapat lebih lancar meskipun pada saat listrik padam, 2) mengupayakan rangkaian alat modulasi yang lebih representatif (modem pool) sebagai pengganti handphone siemens C55 sehingga kebutuhan alat modulasi terpenuhi dan lebih efektif, 3) membuat aplikasi keuangan server pulsa, dan 4) pendampingan kepengurusan $\mathrm{CV}$.

Berdasarkan permasalahan yang telah dibahas pada bab sebelumnya, maka diberikan solusi untuk menyelesaikan permasalahan tersebut, yaitu antara lain:

1. Dibuatkan alat yang dapat mendukung beroprasinya usaha.

2. Dilakukan pembenahan pada manajemen, diharapkan pembagian tugas tenaga kerja semakin jelas dan pengelolaan keuangan semakin baik, sehingga prestasi usaha semakin meningkat.

3. Membuat media pemasaran produk melalui internet, diharapkan dapat memperluas pasar dan meningkatkan permintaan.

4. Dilakukan pendampingan kepengurusan ijin usaha kepada notaris, diharapkan dengan legalitas akan mengamankan posisi mitra secara hukum dan agar mitra dapat berkembang ke arah yang lebih besar

Semantara target luaran adalah sebagai berikut:

1. Menghasilkan alat penyedia daya listrik otomatis sebagai alternatif daya lisrik saat listrik padam.

Alat penyedia daya listrik otomatis bertujuan meningkatkan kelancaran transaksi karena dapat menjadi cadangan listrik. Berikut rangkaian alat yang akan dibuat:

a. Rangkaian instrumen sistem penyedia listrik otomatis. b. Mengusahakan rangkaian alat modem pool 16 untuk menambah jalur modulasi untuk mempercepat dan menstabilkan transaksi.

c. Menghasilkan aplikasi sistem pengelolaan keuangan UKM yang baik sehingga semua transaksi dapat tercatat dan ternalisis dengan baik melalui pembuatan aplikasi keuangan, pelatihan dan pendampingan.

d. Terdaftarnya server pulsa menjadi usaha yang berbadan hukum $\mathrm{CV}$

\section{METODE KEGIATAN.}

\section{Pada aspek Pengembangan alat:}

1. Membuat desain penyedia daya listrik otomatis.

2. Membuat alat sesuai dengan desain yang telah ditetapkan yaitu terfokus pada penyedia daya listrik.

3. Mendemonstrasikan alat yang sudah dibuat pada mitra untuk mengecek kemampuan alat tersebut.

4. Pelatihan dan Pendampingan Tata cara Pemakaian alat.

\section{Pada Aspek Manajemen}

Pada aspek manajemen difokuskan pada pengembangan pengelolaan sistem keuangan yaitu pembuatan aplikasi perhitungan laba rugi, dengam membuatkan aplikasi lengkap berbasis komputer dengan konsep perhitungan laba rugi. Tahap-tahap kegiatan adalah sebagai berikut:

1. Melakukan survei dan analisis kebutuhan sistem keuangan Mitra oleh Tim.

2. Mendesain Aplikasi keuangan Mitra.

3. Mengimplementasikan aplikasi keuangan Mitra.

4. Pelatihan dan pendampingan pengoperasian Aplikasi keuangan kepada Mitra.

\section{Pada aspek kelembagaan:}

Untuk membangun sistem kelembagaan yang baik diperlukan proses diskusi antara tim pelaksana dengan mitra untuk penyamaan persepsi dalam mencari solusi dari permasalahan kelembagaan. Hal ini dimaksudkan untuk menghindari konflik antar sesama UKM server pulsa, dan persaingan harga. Pengurusan badan hukum perlu dilakukan sehingga dapat digunakan sebagai sarana promosi dan membangun kepercayaan konsumen terhadap produk yang ditawarkan dan memperluas jaringan pasar. 


\section{HASIL DAN PEMBAHASAN}

Hasil yang dicapai dalam pengabdian ini pertama adalah menghasilkan beberapa luara sebagai berikut:

1. Rangkaian Modulasi yang bertujuan untuk mempercepat dan menstabilkan proses parsing dalam reload pulsa elektrik.

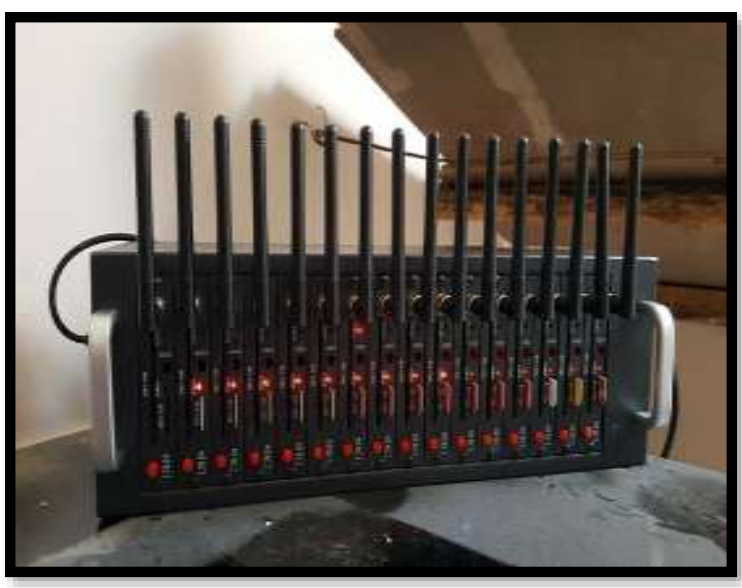

Gambar 1: Alat Modulasi

2. Hasil yang kedua adalah Alat inverter penyedia Listrik.

Komponen ini masih terus dikembangkan dan dalam tahapan ini masih sampai pada penyedia listrik yang bersumber pada jenset setelah sebelumnya diantipasi oleh UPS (Uninterupt Power Suply)

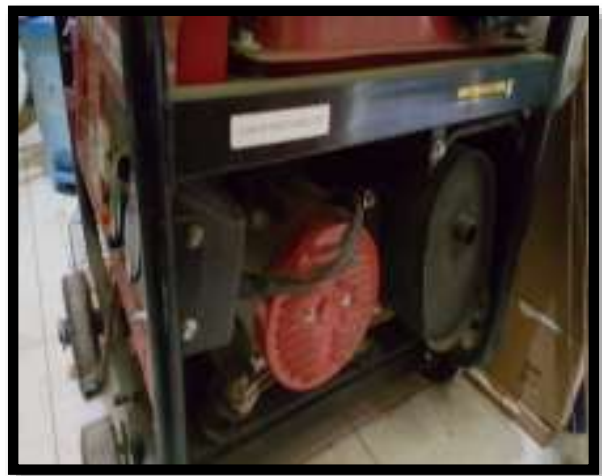

Gambar 2: Alat inverter dan jenset

3. Hasil yang ketiga adalah badan hukum CV mitra.

Dengan memiliki badan hukum CV maka mitra akan memiliki kekuatan kelembagaan sehingga selain menguatkan pada persaingan juga memberi kepercayaan kepada vendor untuk melakukan tender stok pulsa yang lebih besar yang berdampak pada harga yang lebih murah.

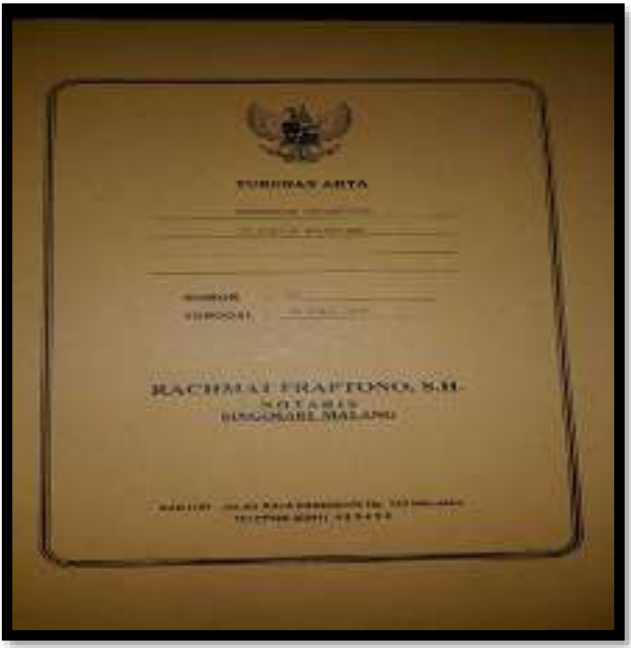

Gambar 3: Badan hukum CV ARPulsabiz

4. Hasil keempat adalah aplikasi keuangan pulsa reload.

Dengan aplikasi keuangan mitra akan sangat terbantu dari segi pengelolaan keuangan, mengingat perputaran dana pulsa yang relatif cepat yang rata-rata omzet Rp. 15.000.000 per hari dengan pelanggan berjumlah kurang lebih 300 pelanggan yang aktif. Maka dengan pengelolaan keuangan yang tersistem dan terkomputerisasi menjadi kebutuhan pokok dalam pengelolaan keuangannya.

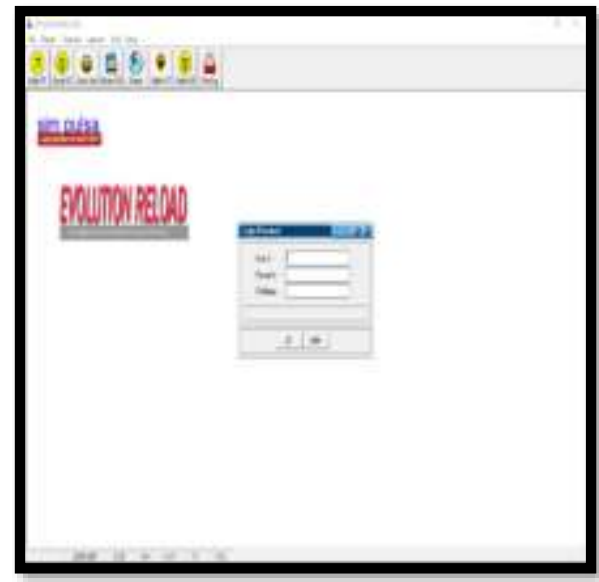

Gambar 4: Aplikasi keuangan

\section{KESIMPULAN}

a. UKM AR-Pulsabiz memiliki alat inverter sebagai media cadangan listrik saat terjadi pemadaman listrik sehingga 
ketidaktersediaan listrik tidak menghambat distribusi pulsa kepada pelanggan.

b. Kedua UKM memiliki rangkaian modulasi dengan metode pool sehingga memperlancar dan menstabilkan pendistribusian pulsa yang berpengaruh pada kepuasan pelanggan.

c. Kedua UKM memiliki bekal aplikasi dan pengetahuan tentang manajemen pengelolaan keuangan UKM sehingga UKM dapat merumuskan strategi yang lebih efektif untuk memajukan usahanya.

d. Kedua UKM memiliki badan hukum CV sehingga memperkuat kelembagaan UKM dalam eksistensinya di masyarakat dan untuk pengembangan usaha selanjutnya.

\section{Hasil Perubahan Efektifitas Transaksi Pulsa pada Mitra.}

Berikut disajikan data perkembangan kelancaran transaksi sebelum diterapkan teknologi modulasi bulan April, Mei, dan Juni (3 minggu pertama), dan setelah diterapkan teknologi pada Juni (Minggu ke-4), Juli, dan Agustus (3 Minggu pertama).

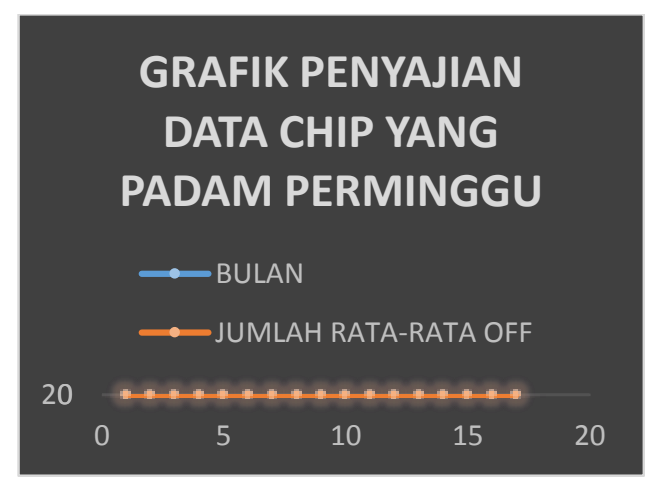

Gambar 5: Grafik Penyajian Data Chip yang Padam Per Minggu
Grafik menunjukkan bahwa terdapat penurunan chip yang padam dengan angka yang drastis semenjak bulan Juli minggu ke-4 dari beberapa minggu sebelumnya dengan rata-rata 14 kali padam per minggu menjadi rata-rata 0 kali. Dari data ini dapat disimpulkan bahwa teknologi modulasi sangat berpengaruh pada kelancaran transaksi.

\section{REFERENSI}

Anonim. "Lima Langkah Membangun Usaha Server Isi Pulsa All Operator". 2007. http://www.serverisipulsa.com/index.php?item =order\&sub- =detail\&id $=2 \#$

T. "Perencanaan dan Pengendalian Produksi". 2002. Ghalia, Jakarta.

Bowo, Dwi A. "Aplikasi Penjualan Voucher dan Pulsa Elektrik Pada Perluasan Cabang CV Dian Mulya Menggunakan Java J2SE, Netbean IDE 6.1 dan MySQL". Gunadarma. 2007.

Putra, R.S., Hariyanto, N., Saodah, Siti. "Perancangan Dan Realisasi Converter Satu Fasa untuk Baterai Menjalankan Motor AC 1 Fasa 125 Watt”. Jurnal Reka Elkomika. Vol. 4, No. 1. ITB.

Simamora, Jona Varto. "Parancangan Emergency untuk Penerangan dan Tenaga pada Ruang Staf Bengkel Listrik dengan Dual Inverter Berkapastias 1000 Watt. 2014.

Subagyo, P. "Manajemen Operasi". 2000. BPFE. 